Vilniaus universiteto Tarptautiniu santykiu ir politikos mokslu institutas,

\title{
Saugumo studijų būklè ir raidos tendencijos
}

\begin{abstract}
Saugumo studijos Europoje išgyvena pakilimą ir yra tapusios naujų teoriju, nauju idejų ir naujų metodų kalve visai tarptautiniu santykiui disciplinai. Trys europietiškos saugumo studijų mokyklos - Kopenhagos, Paryžiaus ir Velso - yra metusios rimtą ǐš̌ūki JAV saugumo/strateginiu studijų ortodoksiniams kanonams apie saugumo problemų supratimą, aiškinimą ir pačią saugumo fenomeno prigimtį. Nepaisant aktyvių tarptautiniu akademiniu mūšiu, Lietuvoje saugumo analizė yra tvirtose geopolitikos gniaužtuose. Vienas kitas kritinis straipsnis kol kas dar nesukūrẻ rimtos alternatyvos stipriai lietuviškajai geopolitikos mokyklai, tačiau tokia alternatyva yra reikalinga ir galètų suteikti šviežų impulsą pačiai Lietuvos saugumo politikai. Straipsnyje aptariama saugumo studijų būklè ir ryškiausios tendencijos, nagrinėjami tradiciniu, amerikietiškuju ir kritiniu, europietiškuju, saugumo studijų skirtumai. Pagrindinis straipsnio tikslas - pristatyti kritinių saugumo tyrimų galimybes, kurios galètų sudaryti svarią alternatyvą racionalistinei prieigai.
\end{abstract}

\section{Ivadas}

Kas yra saugumas? Ar įmanomas visiškas saugumas? Kodèl ir kaip atsiranda saugumo problemos arba saugumo grėsmės? Jau daugiau nei penkiasdešimt metu egzistuojančios saugumo studijos - viena iš tarptautiniu santykių subdisciplinu - vis dar ieško atsakymų į šiuos klausimus. Nepaisant nuolat ir sparčiai augančio teorinėms ir praktinėms saugumo problemoms analizuoti skirtų knygų ir straipsnių skaičiaus, viešajame diskurse nuolat kartojasi ta pati tema - žmonija gyvena nuolatinio nesaugumo sąlygomis. Nesaugumo būklę esą sąlygoja daugybė veiksnių - klimato kaita, stichinès nelaimės, pramoninės avarijos, mirtinų ligų epidemijos, kariniai konfliktai, terorizmas ir kitokios natūralios ar žmogaus veiklos sukeltos priežastys. Teorineje plotmèje saugumo studijos nuolat evoliucionuoja, tampa vis labiau sofistikuotos, keliamos vis naujos hipotezės, taikomi vis nauji, tobulesni analizės ir prognozavimo metodai, tačiau visa tai nepadeda įveikti visuotinio - tiek masinio, tiek individualaus - nesaugumo jausmo. Dar daugiau - kai kuriu saugumo studijų mokyklų issitikinimu, akademikų bandymai siūlyti saugumo

\footnotetext{
* Kęstutis Paulauskas - Vilniaus universiteto Tarptautinių santykių ir politikos mokslų instituto doktorantas. Adresas: Vokiečių g. 10, 01130 Vilnius, tel. 25141 30, el. paštas: kpaulauskas@gmail.com
} 
problemų sprendimo būdus neretai prisideda prie naujų problemų atsiradimo. Iš tikruju galima daryti prielaida, kad egzistuoja pakankamai tamprus ryšys tarp saugumo teorijos ir saugumo praktikos. Skirtingai nei daugelio kitu socialiniu disciplinų ar subdisciplinų atveju, šis ryšys gali turèti egzistencinio pobūdžio pasekmių tiek atskiriems individams, tiek ištisoms visuomenės grupėms ar net valstybėms. 1962 metų Kubos krizės atveju, akademikų žaidimai su racionalaus pasirinkimo teorijomis padèjo atvesti visą pasauli prie susinaikinimo slenksčio, kai Nikita Chruščiovas ir Johnas F. Kenedis èmé žaisti branduolini „Viščiuko žaidimą".

Šaltojo karo metais saugumo teorijos ir praktikos ryšys turëjo paradoksalu pobūdị: saugumo studijos iš esmès "tarnavo" didžiujų valstybiu politikai valstybių dosniai finansuojami saugumo studijų centrai turëjo „moksliškai“ pagrịsti, legitimizuoti šaliu vykdomą saugumo politiką. Saugumo teorija ne šiaip persipynè su saugumo praktika, bet iš esmès tapo jos dalimi, įrankiu. Nuo politikos realijų nepriklausomos saugumo studijos iš esmès neegzistavo.

Dabartinès saugumo studijų tendencijos yra priešingos - kai kurios saugumo studijų srovès nukrypo į išskirtinai teorinę plotmę ir atitrūko nuo praktinių, materialiniu (ne)saugumo fenomeno pasekmių nagrinejjimo. Tokios tendencijos išdava logiška - akademiniuose žurnaluose vykstančios mokslininkų batalijos politiniam elitui yra neįdomios, o plačiajai visuomenei nesuprantamos. Dabartinių saugumo studijų status quo nèra daug žadantis: tradicinės saugumo studijos yra pernelyg užsièmusios saugumo aiškinimu, kad galètu pasiekti gilesnị saugumo supratima, o naujos, kritinės saugumo studiju srovės taip beatodairiškai siekia suprasti saugumą, kad vis dar negali (o dažnai net nesiekia) pasiūlyti bent kiek aiškesnio saugumo aiškinimo. Bandymai susieti abi šias akademines pastangas egzistuoja ir yra būtini bent jau tam, kad saugumo studijos galètų išsaugoti rimtos tarptautinių santykių subdisciplinos statusą ir išvengti pseudomokslinès beletristikos žanro likimo.

Šio straipsnio tikslas dvejopas - aptarti dabartinę saugumo studijų būklę ir jų raidos tendencijas Lietuvoje bei pasaulyje ir atskleisti galimybes naudoti „saugumo“ koncepciją kaip kintamaji (o ne statišką, savaime suprantamą duotybę) tarptautinių santykių/užsienio politikos analizëje. Tuo tikslu bus aptartos ontologinès ir epistemologinès saugumo studijų problemos, analizès lygmens ir analizės vienetu problema, normatyviniai aspektai, saugumo „rašymo“ ir saugumo „praktikos“ distinkcija.

\section{Lietuviškos saugumo studijų „mados“}

Lietuvoje institucinès saugumo studijų ribos pakankamai aiškios: strateginès studijos, geopolitika, kiti tarptautinio ir nacionalinio saugumo problematikai nagrinèti skirti dalykai yra dèstomi Vilniaus universiteto

${ }^{1}$ Prie ,žaidimų teorijos“ plètojimo itin prisidejo ir Nobelio premijos lauretas, „nuostabus protas“ John Nash. 
Tarptautiniu santykiu ir politikos mokslų institute (TSPMI), Lietuvos karo akademijoje, Vytauto Didžiojo universiteto Politikos mokslų ir diplomatijos institute, Klaipėdos universiteto Socialiniu mokslų fakultete.

Lietuvoje veikia ir du strateginiu tyrimu centrai: $2001 \mathrm{~m}$. LKA ịkurtas Strateginių tyrimų centras (direktorè-Jūratè Novagrockienè) ir Egidijaus Motiekos vadovaujamas, $2004 \mathrm{~m}$. ikurtas Strateginių studijų centras. Abu centrai yra finansuojami iš valstybės biudžeto, tad vargu ar gali būti laikomi visiškai nepriklausomais - net ir atlikdami mokslinę, objektyvią analizę, jie vis dèlto vykdo pirmiausia valstybės institucijų užsakymus. Strateginių tyrimu centras atlieka KAM aktualius tyrimus, Strateginiu studiju centras vykdo URM, VSD, KAM užsakymus. Galima neabejoti, kad ir pastarosios institucijos pačios atlieka saugumo problemų analizę, tačiau jos rezultatai paprastai nèra prieinami plačiajai visuomenei. Akivaizdu ir, matyt, natūralu, kad tokiomis salygomis fundamentaliems, teoriniams saugumo tyrimams resursu gali būti skiriama kur kas mažiau negu aktualioms, „paklausioms" nacionalinio saugumo politikos problemoms. Atitinkamai abu tarptautiniu santykiu problemoms nagrinèti skirti žurnalai-Lietuvos metinè strateginé apžvalga ir Lithuanian foreign policy review - taip pat yra orientuoti beveik išskirtinai į užsienio ir saugumo politikos praktika.

Teoriniu lygmeniu, saugumo samprata lietuviškajame tarptautiniu santykiu diskurse yra beveik visiškai uzurpuota geopolitiku (Jonas Daniliauskas, Tomas Janeliūnas, Laurynas Kasčiūnas, Česlovas Laurinavičius, Egidijus Motieka, Nortautas Statkus) ${ }^{2}$ bei tradiciniu saugumo studiju atstovu (Gediminas Vitkus, Vaidotas Urbelis, Egidijus Vareikis, Evaldas Nekrašas. Debatai dẻl Nato ateities „Lietuvos metinè strateginè apžvalga 2002, Vilnius, LKA, $2003)^{3}$. Kritinė saugumo samprata yra atstovaujama vos vieno kito autoriaus (pirmiausia Gražina Miniotaitè, Dovilè Jakniūnaitė) ${ }^{4}$. Statkus ir šio straipsnio autorius taip pat yra bandę polemizuoti saugumo studijų ir Lietuvos saugumo politikos klausimais ${ }^{5}$. Be minètų autoriu, daugelis kitų Lietuvos politologu,

\footnotetext{
${ }^{2}$ Šie autoriai yra dèstę ar dèsto su saugumo studijomis ar geopolitika susijusias disciplinas, yra ne vienos knygos ir straipsnio autoriai, pvz., Č. Laurinavičius, E. Motieka, N. Statkus, Baltijos valstybiu geopolitikos bruožai. XX amžius, Vilnius: Lietuvos Istorijos instituto leidykla, 2005; Daniliauskas J., Janeliūnas T., Kasčiūnas L., Motieka E., Šiaurès šaliu geostrateginè svarba Lietuvai, Vilnius: Eugrimas, 2005.

${ }^{3} \mathrm{G}$. Vitkus yra Lietuvos metinės strateginès apžvalgos atsakingasis redaktorius, daugelio straipsnių autorius, Žr.: Vitkus G., „Rusijos-JAV-ES „,trikampis“ir mažesnès valstybės 2003-2004 metais“, žr.: Lietuvos metine strategine apžvalga 2004, p. 129-152. Urbelis dèsto strategines studijas TSPMI ir yra daugelio straipsniu saugumo temomis autorius, žr.: Urbelis V., Lietuvos vieta JAV didžiojoje strategijoje, Vilnius: Lietuvos karo akademija, 2005. E. Vareikis dèsto nacionalinio ir tarptautinio saugumo dalyką VDU, taip pat yra parašęs straipsniu šia tema, pvz.: Vareikis E., „Kas yra nacionalinis saugumas?“, Skaitiniai apie nacionalini ir tarptautini sauguma, Vilnius: 2000, p. 7-12.

${ }^{4} \mathrm{G}$. Miniotaite yra ne vienos studijos tarp disciplinu autorè, aktyviai dalyvaujanti europietiškajame kritiniu saugumo studijų diskurse. Jakniūnaitė dėsto ir atlieka tyrimus socialinio konstruktyvizmo srityje. Pvz., žr.: Miniotaitė G., Jakniūnaitė D., „Lietuvos saugumo politika ir identitetas šiuolaikinių saugumo studijų požiūriu“, Politologija 3, 2001, p. 21-43; Miniotaite G., „Convergent Geography and Divergent Identities: A decade of transformation in the Baltic states", Cambridge Review of International Affairs 16 (2), 2003, p. 209-222; Miniotaitė G., „Tapatybės paieškos šiuolaikinėje Lietuvos užsienio politikoje: tarp Šiaurės ir Rytu dimensijų“, Lietuvos metinè strateginé apžvalga 2004, Vilnius: Lietuvos karo akademija, 2005, p. 83-99. ${ }^{5}$ Statkus N., Paulauskas K., „Lietuvos užsienio politika tarptautinių santykių teorijų ir praktikos kryžkelëje“, Politologija 06/2, p. 12-60.
} 
žurnalistu, politikos apžvalgininkų ir politikų dažnai komentuoja įvairius Lietuvos ar tarptautinès saugumo politikos aspektus.

Nepaisant tokios saugumo ekspertų ir analitiku gausos, pagrindinejje tarptautinių santykių specialistus rengiančioje aukštojoje mokykloje - TSPMI per nepriklausomybès laikotarpį buvo apginta tik viena disertacija, skirta išskirtinai saugumo studiju problemoms nagrinèti: Janeliūno darbas „Komunikacinio saugumo koncepcija saugumo tyrimuose“.

Pakankamai siauras Lietuvos saugumo ekspertu akiratis, dažnai apsiribojantis nacionalinemis Lietuvos saugumo problemomis, galbūt ir nepakankamos anglų kalbos žinios, sąlygoja menką Lietuvos akademinės minties atstovavimą tarptautiniame saugumo studiju diskurse: lietuviu autoriu straipsniu pripažintuose tarptautinių studijų žurnaluose yra vienetai. Viena tokios (savi)izoliacijos pasekmių ta, kad Lietuvoje šiandien itin madinga geopolitika Europos saugumo studijų kontekste atrodo šiek tiek anachronistiškai. Kita vertus, geopolitika tebèra itin populiari Rusijoje (pirmiausia Aleksandro Dugino asmenyje ${ }^{6}$, taip pat čia yra leidžiamas almanachas Geopolitika), Kinijoje (kartu su Italijos mokslininkais leidžiamas žurnalas Heartland); Prancūzijoje (čia veikia Prancūzijos geopolitikos institutas); iš dalies ir JAV (leidžiamas žurnalas Geopolitics), tačiau tokiame didžiujų valstybių kontekste geopolitikos dominavimas Lietuvoje taip pat atrodo ne visiškai adekvatus. Galima būtu sutikti su prielaida, kad lietuviškosios geopolitikos mokyklos atsiradimą sąlygojo sudètinga Lietuvos geopolitinè padètis. Kita vertus, patys geopolitikai lietuviškame saugumo diskurse ir įtvirtino tezę, kad Lietuvos geopolitiné padètis yra sudètinga, todèl Lietuvai yra būtina stipri geopolitikos mokykla, kuri galètu paaiškinti, ką ši tezė reiškia. Nors tokia logika atrodo šiek tiek tautologiška, ji šiandien yra įsitvirtinusi ir ịgijusį dogmatišką pobūdị viešajame Lietuvos saugumo diskurse. Dominuojantis šio diskurso naratyvas teigia, kad Lietuva turi daug vidaus ir išorės saugumo problemu, kurios vienaip ar kitaip yra susijusios su grėsmingu, priešišku kitu - Rusija. Akademinės geopolitikos ir saugumo ekspertu pastangos ir yra sutelktos siūlyti šių realiomis, objektyviomis laikomų problemų praktinius sprendimų būdus.

Tokiomis saugumo studijų būklès sąlygomis, Lietuvoje teoriniu lygmeniu saugumo koncepcija nèra problematizuojama. Dèl šios priežasties Lietuvoje saugumas tiek akademiniame, tiek politiniame diskurse aiškinamas/rašomas ir praktikuojamas tradicine, pozityvistine prasme - kaip valstybės saugumas nuo objektyvių, išorinių politinių, karinių, ekonominių ir kitokiu grèsmių.

Kituose skyriuose bus aptarta tiek tradicinès saugumo sampratos evoliucija, tiek ir jai mestas alternatyvių, kritinių mokyklų iššūkis, teigiant, kad pastaruju ižvalgos galètų papildyti Lietuviškajji saugumo supratimą.

${ }^{6}$ Dugin A., Osnovy geopolitiki, Moskva: Arktogeja-centr, 1999. 


\section{Saugumo studijų raida}

Saugumas yra viena pagrindinių tarptautiniu santykių disciplinos koncepcijų. Kartu tai yra „iš esmès ginčijama“ sąvoka7, dèl kurios apibrèžimo ir turinio iki šiol yra nesutariama. Dar daugiau - šiandien dèl šios sąvokos nesutariama labiau nei bet kada anksčiau.

Nuo pat $1648 \mathrm{~m}$. Vestfalijos sutarties "saugumo" sąvoka buvo siejama su valstybe. Saugumas iš esmès reiške gynybq nuo organizuotos prievartos iš užsienio, t.y. grẻsmingu „,kitü“. Teritorinè valstybè tapo tuo organizuojančiu principu, kuris leido atskirti, diferencijuoti „mus“ nuo „kitu“. Karinès jẻgos telkimas padejo konsoliduoti pačią valstybę: prievartos instrumentų - kariniu pajėgumu - kūrimas padarẻ valstybę pagrindiniu saugumo teikèju, tačiau kartu ir pagrindiniu jo interpretatoriumi. Didžiają pasaulio istorijos dalį "saugumo" reikšmè apskritai buvo tokia, kokią jam suteikdavo valdovai. ${ }^{8}$

Saugumas galutinai igijo modernią - valstybės atributo, užtikrinamo karinėmis ir diplomatinėmis priemonėmis - prasmę XVIII a. pabaigoje. Rousseau, Locke'o ir Montesquieu socialinio kontrakto teorijos padèjo ịtvirtinti saugumo sąvoką politiniame diskurse ${ }^{9}$. „Socialinis kontraktas“ turëjo išplěšti individą iš anarchiškos visų karo prieš visus būklès ir suteikti jam laisvę bei saugumą. Didžioji Prancūzijos revoliucija „šiek tiek“ pakoregavo kilnius filosofų tikslus - individų saugumas buvo tiesiog mechaniškai subordinuotas tautos saugumui.

"Nacionalinis saugumas" yra dar naujesnè sąvoka. Iki II pasaulinio karo pabaigos "saugumo" ir "gynybos" sąvokos dažnai buvo naudojamos kaip sinonimai. Net ir karo paskelbimas paprastai buvo (dažnai ir tebėra) įvardijamas kaip gynyba. Valstybès ",saugumo“ sąvoka ne karo metu neturëjo prasmès ir politiniame diskurse iš esmès neegzistavo. Nacionalinio saugumo šaukliais tapo amerikiečiai, $1947 \mathrm{~m}$. prièmę Nacionalinio saugumo aktą. Gynybos sąvoka ir jos uždèti teritoriniai bei mentaliniai apribojimai jau turëjo per silpną semantinį krūvị siekiant mobilizuoti JAV visuomenę beprasidedančiam Šaltajam karui. "Nacionalinio saugumo“ koncepcija turèjo tapti ir tapo tikra saugumo studiju alma mater.

Saugumo studijos klasifikuojamos įvairiai. Pagal vienus autorius, yra vienos saugumo studijos, kurios tiesiog evoliucionuoja (pvz. Barry Buzan'as, pats daug prisidejęs prie tokios evoliucijos). Kiti autoriai (pvz., Ken Booth'as) skiria du periodus - tradiciniu saugumo studiju (Šaltasis karas) ir kritiniu saugumo studiju periodas (po Šaltojo karo). Pagal Bill McSweeney, saugumo studijos (kaip ir tarptautiniu santykiu disciplina) išgyveno 4 cikliškus periodus - politinès teorijos, politikos mokslo, politinès ekonomikos ir sociologijos - tačiau visuose šiuose perioduose kartojosi dvi pagrindinès idejjos -

\footnotetext{
${ }^{7}$ Plačiau apie iš esmès ginčijamas sąvokas: Gallie W. B., „Essentially contested concepts“ žr.: Black M., eds., The importance of language, Englewood Cliffs, New Jersey, 1962, p. 121-146.

${ }^{8}$ Del Rosso Jr., S. J., „The Insecure State (What Future for the State?)“, Daedalus 124 (2), 1995, p. 183.

${ }^{9}$ McSweeney B., Security, Identity, and Interests: A Sociology of International Relations, Cambridge:

Cambridge University Press, 1999, p. 19.
} 
"nacionalinio saugumo" ir "bendro saugumo" ${ }^{10}$ Kaip visoje tarptautiniu santykių disciplinoje, kurioje vietoj „žinojimo“ akumuliacijos, būdingos „,normaliems mokslams“, dažnai keičiasi „didžiujų debatu“" ir "schizmų" dalyviu pavadinimai, bet nesprendžiamos esminès problemos, taip ir saugumo studijose dažnai keitėsi įvairių teorinių mokyklų vardai, bet „žinių“ akumuliacijos kryptimi buvo nueita nedaug.

Bet kokiu atveju, saugumo studiju chronologija yra pakankamai trumpa. Pirmasis saugumo studiju periodas iš esmès sutampa su idealizmo era tarptautinių santykių disciplinoje. Prieš Antrojo pasaulinio karo pradžią ir jam pasibaigus kurị laiką dar sklande „,bendro saugumo“ idèja, kurios ištakas galima atsekti nuo W. Wilsono ir Tautų Lygos, ir kurią bandyta įdiegti Jungtiniu Tautu chartijoje. Edward H. Carr ${ }^{11}$ ir ypač Hans Morghenthau ${ }^{12}$ realizmo teorija padejjo pagrindus saugumo studiju „,aukso amžiui“ - strateginių studiju erai. Beje, būtina turèti omeny semantinius skirtumus tarp JAV ir Europos tarptautinių santykių mokyklu. JAV iki šiol iš esmès nediferencijuojama tarp strateginiu ir saugumo studijų. Europoje strateginès studijos suprantamos siaura, karo studiju prasme, o saugumo studijos apima visus saugumo „sektorius". Neoliberalu mokykla (Robert Keohane, Joseph Nye ${ }^{13}$ ) bandè mesti iššūki realistams su "tarpusavio priklausomybès" teze, kuri iš esmès buvo labiau sofistikuota "bendro saugumo" idèjos versija. Pagaliau kai netikèta Šaltojo karo pabaiga pakirto tradicinio saugumo strategu autoritetą, daugybe įvairų srovių èmè siūlyti savus saugumo koncepcijos plètimo ir gilinimo projektus, tačiau iš prestižinių mokslo institucijų, tyrimų centrų ir tarptautinių studijų žurnalų puslapių tradicinès saugumo sampratos apologetu iki šiol neišstūmè. Tiesa, JAV „viduriniojo kelio“ konstruktyvistai (Emmanuel Adler, Alexander Wendt) konstruktyvaus dialogo su (neo)realistais dẻka savotiškai legitimizavosi ir tapo rimtais dominuojančio tarptautinių santykių disciplinos diskurso dalyviais, tačiau radikalesnès, postmodernistinès srovès taip ir liko už šio diskurso ribų. Europoje netradiciniai požiūriai tradiciškai gyvuoja sẻkmingiau. Amerikietiškojo ir europietiškojo konstruktyvizmo variantų skirtumai atsispindi žurnalų International Organization (leidžiamas Harvarde, JAV) ir Millenium (leidžiamas Londone) bei European Journal of International Relations (leidžiamas Miunchene) publikacijose.

Šiandien būtu galima teigti, jog konstruktyvizmas Europoje savo populiarumu bent akademinio diskurso lygmeny ima išstumti neo-neo sintezės atstovus. Vis dèlto tiek JAV, tiek Europoje dèl įvairiu priežasčiu nauju saugumo studiju srovių atstovai dar nerado būdų daryti įtaką tarptautinès politikos praktikai, o kai kurios kritinės mokyklos netgi griežtai pasisako prieš saugumo teoretikų bandymus paveikti politika.

Vis dèlto šiandien saugumo studijos yra viena dinamiškiausiu Tarptautinių santykių subdisciplinų. Kai kurių autorių teigimu, būtent iš sau-

\footnotetext{
${ }^{10}$ Ten pat, p. $28-30$.

${ }^{11}$ Carr E. H., The Twenty Years ' Crisis 1919-1939, London: Macmillan, 1946.

${ }^{12}$ Morgenthau H., Politics Among Nations, New York, Knopf, 1948.

${ }^{13}$ Keohane R., Nye J., Power and Interdependence, Boston: Little, Brown, 1977.
} 
gumo studiju, tradiciškai konservatyviausios ir uždariausios subdisciplinos, ateina „,naujų impulsų" visai Tarptautinių santykių disciplinai, būtent saugumo studijose vyksta aktyviausi debatai ${ }^{14}$. Pagaliau juk būtent saugumo studijas galima laikyti galingiausia ir svarbiausia realizmo citadele, todèl net ir nedideli laimëjimai šioje srityje konstruktyvistų stovyklai yra itin saldūs.

Būtina pabrèžti, kad įvairių saugumo studijų krypčių ar mokyklų debatai savo esme skiriasi tarp JAV ir Europos tarptautinių santykių tradiciju. JAV saugumo studijose pagrindiné skiriamoji linija yra tarp „ofenzyvinio“ realizmo ir "gynybinio" realizmo. Šių centrinių debatų paraštėse dar egzistuoja poklasikinis realizmas, „viduriniojo kelio“ konstruktyvistų saugumo sampratos, pasaulio tvarkos teoretikai, susiję su neokonservatoriais ir iš dalies tradicinio liberalizmo tradicija. Europoje šalia tradicionalizmo (politikos realizmo) vyksta itin aktyvūs debatai tarp kritinių srovių - Kritinių saugumo studijų, Kopenhagos mokyklos ir Paryžiaus mokyklos. Šių debatų paraštėse taip pat galima rasti ir radikalaus postmodernizmo bei feminizmo atstovu. Tokios saugumo sampratu proliferacijos sąlygomis tradicinès saugumo studijų atstovai ima prarasti turètą intelektualinès monopolijos ,"saugumą “15. Šiuolaikinių saugumo studijų „žemėlapis“ šiandien iš tikrujų margas (žr. 1 schemą).

\footnotetext{
${ }^{14}$ Williams, M. C. „Words, Images, Enemies: Securitization and World Politics“, International Studies Quarterly 47 (4), p. 511-531.

${ }^{15}$ Pvz., žr.: Smith S., „The Increasing Insecurity of Security Studies: Conceptualizing Security in the Last Twenty Years“ žr.: Croft S., Terriff T., eds., Critical Reflections on Security and Change, London: Frank Cass, 2000, p. 72-101.
} 


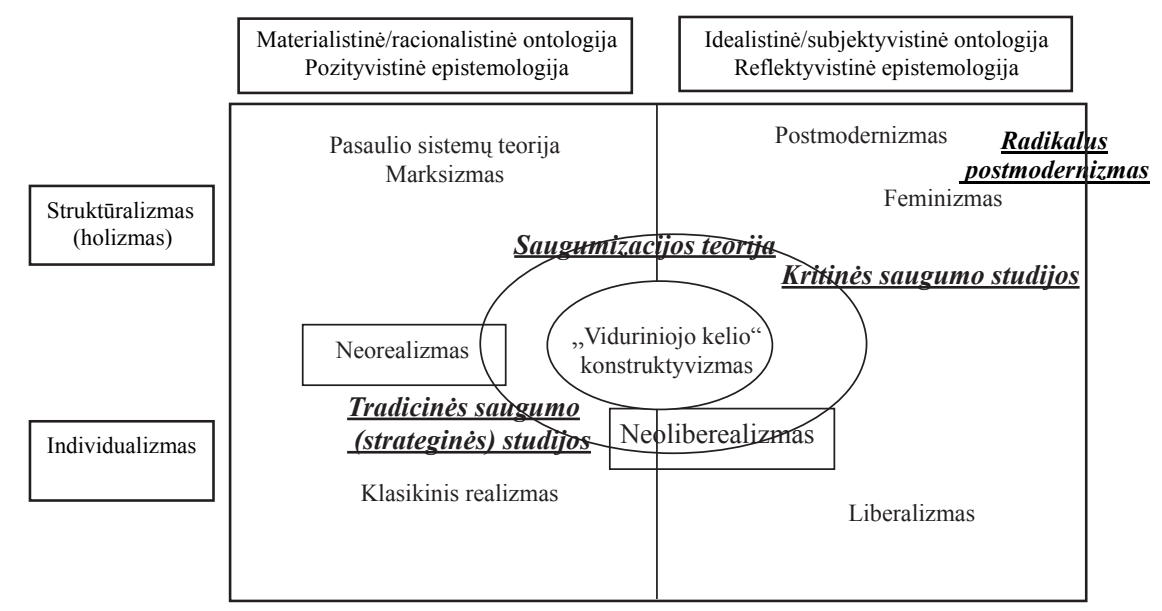

1 schema. Saugumo studijụ teorinès kryptys tarptautiniụ santykiụ teorijos kontekste

\section{Saugumas, kaip viskas ir niekas}

Šiuolaikinèse saugumo studijose vyrauja keturi pagrindiniai klausimai, dèl kurių sprendimo nesutaria skirtingos mokyklos ${ }^{16}$ :

- Kas yra saugumo objektas? Kitaip tariant, „kieno“ saugumas? Priklausomai nuo teorinès prieigos, saugumo objektas gali būti individas, grupè, bendruomenè, valstybė ar net visas pasaulis - bet kas nuo „nieko“ iki „visko".

- Kokia yra grèsmių prigimtis? Saugumas nuo ko? Atsakymai vèlgi gali būti įvairūs - nuo kariniu grẻsmių iki kultūrinių ar aplinkosauginių veiksnių.

- Kas yra tas subjektas, kuris gali suteikti saugumą? Individai, kariuomenè, valstybè, valstybiu sajungos?

- Kaip, kokiomis priemonėmis saugumas gali būti suteiktas?

Tačiau visi šie klausimai preziumuotu, kad atitinkama mokykla jau turi atsakymą į esmini klausimą: kas yra saugumas? Kaip teigia vienas postmodernistu R. B. J. Walkeris, „,nacionalinio saugumo“ sąvoka skatina ne tik tokią "realybę" ir "būtinybę", kurią visi privalo pripažinti, bet ir itin aptakius apibendrinimus apie jau minètus „viską" ir "nieką" ${ }^{\text {"17 }}$. Anot šio autoriaus,

${ }^{16}$ Aggestam L., Hyde-Price A., eds., Security and Identity in Europe. Exploring the New Agenda, London: Macmillan Press Ltd, 2000, p. 3-6.

${ }^{17}$ Walker, R.B.J. "The Subject of Security", in: Krause K., Williams M., eds., Critical Security Studies:

Concepts and Cases, London: UCL Press, 1997, p. 63 
būtent tikrų dalykų netikrumas yra pagrindinė problema. ${ }^{18}$ Saugumo sampratu paletė iš tikrujų itin plati: nuo siauros, aiškiai apibrèžtos, tradicinės saugumo sampratos, iki visko, ką "mes vadiname saugumu“.

\subsection{Tradicinè saugumo samprata}

Tradicinėse saugumo/strateginėse studijose saugumo samprata nėra problema. Saugumas net nèra konceptualizuojamas - jis tiesiog turi vieną aišku apibrěžimą. Pagal Stephen'ą Walt'ą, saugumo studijų tikslas - žinių apie karinę jègą akumuliavimas. Saugumo studijos tiria grèsmes, karinès jëgos panaudojimą, jos pasekmes valstybėms ir visuomenėms, valstybiu politiką rengiantis karams ar kariaujant ${ }^{19}$. Saugumas apibrèžiamas tautologiškai: saugumas yra valstybès saugumas nuo išorinių (pirmiausia kariniu) grèsmiu, o valstybės ir jos gyventoju saugumą garantuoja... ta pati valstybė. Taigi tai iš esmès ikiteorinè, pozityvistinė tezè. Neorealistinè saugumo ontologija yra gerai žinoma: valstybės yra pagrindiniai tarptautinių santykių subjektai, o anarchija - nuolatinè tarptautinès sistemos būklè, todèl valstybės siekia didinti galią, kad užsitikrintų saugumą. Tarptautinè sistema, nacionaliniai interesai ir saugumo politika yra susiję griežtais priežastiniais ryšiais: anarchiška tarptautinė sistema nulemia racionalu, egoistinị siekị didinti galią ir saugumą, tuo tikslu vykdoma saugumo politika savo ruožtu gali paveikti galios balansą tarptautinëje sistemoje.

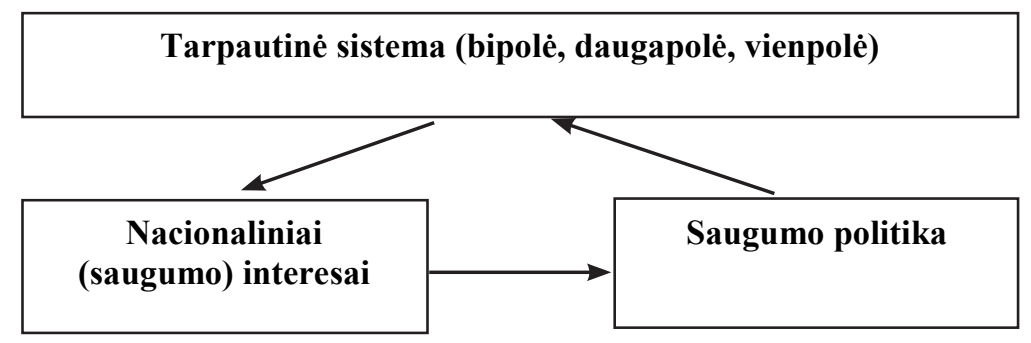

2 schema. Tradicinè saugumo samprata

Tradicine prasme saugumas yra materialinè kokybè. Jo gali būti daugiau ar mažiau, tačiau anarchiškoje tarptautinëje sistemoje valstybės visada jausis nesaugios ir sieks saugumą padidinti. „Ofenzyvinio“ realizmo šalininkai agituoja už valstybės galios ir ịtakos didinimą kitu valstybių atžvilgiu ${ }^{20}$, ,gynybinio" realizmo šalininkai rekomenduoja tik balansuoti prieš kitas galias ${ }^{21}$ ar grèsmes ${ }^{22}$. Taigi saugumas yra negatyvi kategorija, absoliutus saugumas neįmanomas, saugumo problema yra „nesaugumas“. Anot klasikinio realizmo

\footnotetext{
${ }^{18}$ Ten pat, p. 76.

${ }^{19}$ Walt S. M., „The renaissance of security studies“, International Studies quarterly 35, 1991, p. 212.

${ }^{20}$ Pvz., Mearsheimer J. J., The Tragedy of Great Power Politics, New York: Norton, 2001.

${ }^{21}$ Waltz K., Theory of International Politics, New York: McGraw-Hill, 1979.

${ }^{22}$ Walt S., The origins of alliances, Ithaca: Cornell University Press, 1987.
} 
atstovo Arnold'o Wolfers'o, „saugumas yra niekas kitas, kaip nesaugumo nebuvimas, negatyvi vertybe $\dot{e}^{\prime \prime 23}$.

Realistineje epistemologijoje pagrindiniai nepriklausomi kintamieji yra geografinè/geopolitinè šalies padètis ir turima galia, priklausomi - saugumas ir padètis/statusas tarptautinèje sistemoje. Realistų teigimu, silpnesni tarptautinès arenos veikejjai gali stiprinti savo saugumą vykdydami tokią politiką, kad kitiems tarptautinès sistemos veikëjams nekiltų jų atžvilgiu priešišku intencijų arba jie gali didinti savo galią ir taip neleisti priešiškoms valstybėms realizuoti savo ketinimų. Valstybès gali stiprinti galią dviem būdais: pačios telkdamos resursus - tai vidinis balansavimas (resursų mobilizacija, ginklavimasis ir t. t.) arba jungdamos su kitomis valstybėmis (ar tarptautinès politikos subjektais), priešiškai nusiteikusiomis galimo priešininko atžvilgiu - tai išorinis balansavimas. Stipresni tarptautinės arenos veikëjai labiau linkę pasikliauti savarankišku galios didinimu (vidiniu balansavimu), nors nevengia formuoti aljansu, į savo pusę patraukdami ir silpnesnes valstybes. Mažosios ir vidutinès valstybės yra linkusios į išorinị balansavimą - prisišliejimą prie didžiujų valstybių (taip pat ir revizionistiniu) ar hegemono.

Visos šios tezės tradicinėse saugumo studijose yra objektyvios „tiesos“ ir "faktai“. Kritinès mokyklos jas vertina tik kaip prielaidas ir ịsitikinimus, dargi turinčius nemažą normatyvinį ar net neslepiamą politinį krūvị. Kitaip tariant, tradiciné saugumo samprata yra politinis sprendimas, kuris nuolatiniu karu istorijos kontekste atrodytų visiškai logiškas, jeigu nebūtų pats daręs didelès įtakos tokios istorijos rašymui.

Galima atsekti savotišką šios saugumo sampratos kūrimo „strategiją“: XVI-XVII a. feodalinëje viduramžių sistemoje saugumo subjektų bei objektu buvo daugybè: feodalai, monarchai, bažnyčios - visi kas tik galëjo samdyti kariuomenę ir ginti savo teritoriją ar kitą valdžios šaltinị (pvz., religiją, sostą ir pan.). Vestfalijos sistema efektyviai susiaurino saugumą: valstybe tapo vidaus saugumo ir tvarkos garantu, atskyrusiu gyventojus nuo pavojingos išorès. Ši sistema gana efektyviai veike iki pat XX a. pabaigos, todèl kritinių sroviu atstovai bandydami keisti ar plèsti šią sampratą patenka i̇ savotiškus spąstus: jie arba turi turèti sąmoningą politinę darbotvarkę, arba jų neįsisąmonintos akademinės pastangos turės eklektišku, neplanuotu politinių pasekmių.

Kintančių tarptautinės politikos realijų (neo)realistai negalëjo nepaisyti ir patys bandè plèsti savo saugumo sampratą. Klasikinis veikalas šiuo požiūriu yra B. Buzano „Žmonès, valstybės ir baime“" , kurio pirmas leidimas pasirodè dar 1983 m. ${ }^{24}$ Buzanas tradicinę saugumo sampratą mechaniškai išplètė iš vieno karinio į dar keturis sektorius - politinị, ekonominį, ekologinį ir socialinį, tačiau saugumo subjektu (tai yra tuo, kas teikia saugumą) ir objektu (tai yra tuo, kas turi būti apsaugota) išliko valstybẻ. Buzano požiūris į saugumą ir po $1983 \mathrm{~m}$. evoliucionavo ir plètėsi (žr. 1 lentelę).

\footnotetext{
${ }^{23}$ Wolfers A., Discord and Collaboration: Essays on International Politics, Johns Hopkins Press, Baltimore, 1962, p. 153.

${ }^{24}$ Buzan B., Žmonès, valstybès ir baimé, Vilnius: Eugrimas, 1997.
} 
1 lentelè. B. Buzano saugumo analizès evoliucija: saugumo sektoriai ir objektai

\begin{tabular}{|c|c|c|c|c|c|c|}
\hline & & \multicolumn{5}{|c|}{ Sektoriai } \\
\hline & & Karinis & Politinis & Ekonominis & Ekologinis & Socialinis \\
\hline $1983 \mathrm{~m} . *$ & \multirow{3}{*}{$\begin{array}{l}\text { Saugumo } \\
\text { objektas }\end{array}$} & \multicolumn{5}{|c|}{ Valstybė } \\
\hline 1993 m.** & & \multicolumn{4}{|c|}{ Valstybė } & Identitetas \\
\hline $1998 \mathrm{~m} . * * *$ & & Valstybè & Suverenitetas & $\begin{array}{l}\text { Nacionalinè } \\
\text { ekonomika }\end{array}$ & $\begin{array}{l}\text { Aplinka, } \\
\text { klimatas }\end{array}$ & Identitetas \\
\hline
\end{tabular}

* knygos Žmonés, valstybés ir baimé pirmas leidimas

** knyga Waever O., Buzan B., Kelstrup M., Lemaitre P., Identity, Migration and the New Security Agenda in Europe.

*** knyga Buzan B., Waever O., de Wilde J., Security: a New Framework for Analysis

1993 m. Buzanas tapo vadinamosios Kopenhagos mokyklos nariu, kuri „socialinį identitetą" iškèlè kaip valstybès suverenitetui lygiavertị saugumo objektą. Anot šios mokyklos atstovu, jeigu valstybė praranda suverenitetą, ji nustoja egzistuoti kaip valstybė. Atitinkamai, jeigu visuomenè praranda savo identiteta, ji nustoja egzistuoti kaip visuomené2 ${ }^{25}$.

„Viduriniojo kelio“ konstruktyvizmo autoriai netruko suteikti identitetui centrinę vietą valstybės užsienio ir saugumo politikos formavime: valstybės identiteto pokyčiai tiesiogiai veikia jo interesus ir politiką ${ }^{26}$ (žr. 3 schemą). Kitaip tariant, veikèjai negalètų nuspręsti, kokie yra jų interesai, jeigu pirmiausia nežinotu, kas yra jie patys.

Tačiau ir šis bandymas plètoti saugumo sampratą ne tiek pagilino saugumo supratimą, kiek ji mechaniškai išplètė, pridedant dar vieną kintamaji tapatybę. Taip atsirado „nacionalinio saugumo kultūros“ sąvoka, tačiau dèl to saugumo samprata netapo mažiau "nacionaline“ ir labiau "kultūrine“.

\footnotetext{
${ }^{25}$ Waever O., Buzan B., Kelstrup M., Lemaitre P., Identity, Migration and the New Security Agenda in Europe, London: Pinter, 1993, p. 25.

${ }^{26}$ Jepperson R. L., Wendt A., Katzenstein P.J. „Norms, Identity, and Culture in National Security“, žr. Katzenstein P. J., ed., The Culture of National Security: Norms and Identity in World Politics, New York: Columbia University, 1996, p. 33-78.
} 


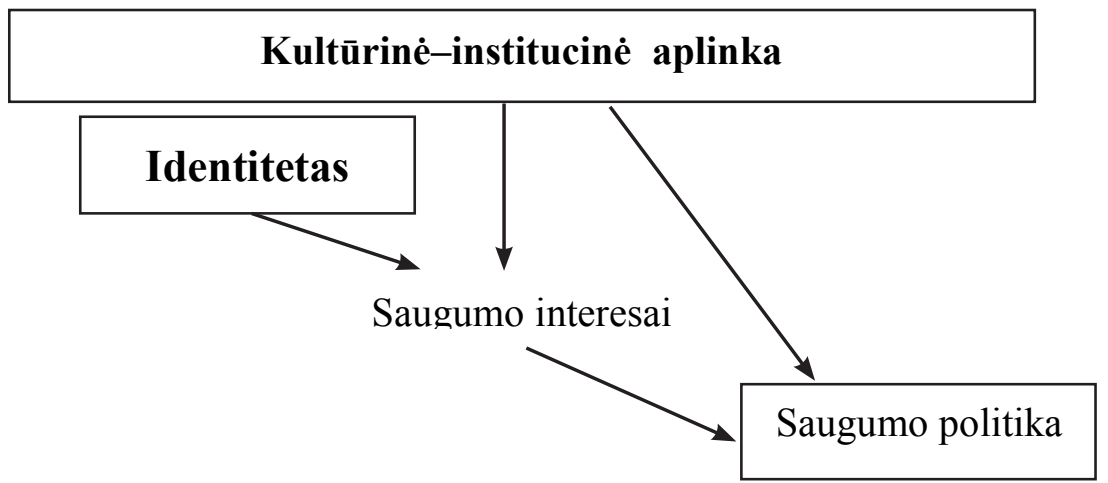

3 schema. „Viduriniojo kelio“ konstruktyvizmo saugumo samprata ${ }^{27}$

\subsection{Kritinès saugumo sampratos}

Šaltojo karo pabaiga sudavè didelị smūgị neorealistinei saugumo studiju citadelei, tačiau jos nesugriovè. Nors kritinès mokyklos iš visų pusių ėmè pulti tradicinę saugumo sampratą ir ją visais įmanomais būdais plèsti bei gilinti, patys tradicionalistai atkakliai skelbe tradiciniu saugumo studiju ",renesansą ${ }^{\prime \prime 28}$. Europoje išsikristalizavo trys kritiniu saugumo studiju mokyklos ${ }^{29}$ : Kritinès Saugumo Studijos (ang. CSS - Critical Security Studies), kitaip dar vadinama Velso arba Aberystwyth mokykla; Kopenhagos mokykla ir Paryžiaus mokykla. Visas jas sieja saugumo sampratos problematizavimas ir atsargus požiūris ì saugumo koncepcijos plètimą dèl galimu politinių pasekmiu, tačiau yra ir reikšmingų skirtumų. Būtina pabrěžti, kad kitame skirsnyje pateikiamas glaustas šių mokyklų idëjų aptarimas nepretenduoja į objektyvią, visapusišką ir baigtinę analizę - apsiribojama, autoriaus nuomone, svarbiausių teoriniu gijų subjektyvia interpretacija.

\footnotetext{
${ }^{27}$ Source: Jepperson et al., (26 išnaša)

${ }^{28}$ Pvz., Walt, (22 išnaša), taip pat Mearsheimer J., „Back to the Future: Instability in Europe after the Cold War", International Security, 15(1), 1990, p. 5-56.

${ }^{29}$ Waever O., Aberystwyth, Paris, Copenhagen New ,Schools “ in Security Theory and their Origins between Core and Periphery, paper presented at the annual meeting of the International Studies Association, Montreal, March 17-20, 2004
} 


\subsubsection{Velso mokykla}

Kritiniu Saugumo Studiju ${ }^{30}$ (Velso mokyklos) ištakos - 1991 m. K. Booth'o straipsnis $^{31}$ ir 1997 m. Keith Krause bei Michael Williams redaguota straipsniu antologija "Critical Security Studies ${ }^{\prime \prime 32}$. Šios mokyklos centrinè tezè yra Booth'o teiginys, jog saugumas turètų būti suprantamas kaip emancipacija, žmonių-individu ar grupių - iš(si)laisvinimas nuo fizinių ar kitokių apribojimų - skurdo, prievartos, politinès priespaudos ir t. t. Saugumo analitikai turètų vengti žiūrèti į saugumą per valstybės prizmę - pati valstybė dažnai gali būti problemos priežastis, o ne sprendimas, kaip implikuotu „nacionalinio saugumo“ koncepcija. Geriausias būdas konceptualizuoti saugumą yra susieti jị su individais, žmonèmis, ir aiškinti emancipacijos terminais.

İdomu tai, kad Velso saugumo studijų ontologija yra artimesnė objektyvizmui nei reflektyvizmui: ši mokykla, kaip ir realistai, teigia žinanti „tikrają“ saugumo sąvokos reikšmę. Nors Ole Waever teigia, kad ši mokykla siekia nagrinèti „realias“ grèsmes „realiems“ žmonėms ${ }^{33}$, patys mokyklos atstovai kitaip nusako savo normatyvinę darbotvarkę. Waever, atrodo, neužčiuopa pagrindinio skirtumo tarp jo Kopenhagos mokyklos ir Velso mokyklos. Velso mokyklos saugumo samprata savo prigimtimi yra pozityvi. Šios mokyklos atstovas McSweeney veda analogiją tarp Isaih Berlino negatyviosios ir pozityvios laisvès idejjų ir negatyviojo ir pozityviojo saugumo sampratų. Kaip ir laisvè, saugumas gali igyti tiek negatyvią („,saugumas nuo ko?“), tiek pozityvią (,,saugumas kam?“) formas. Pastaruoju atveju grėsmės sąvoka tiesiog neegzistuoja. Remiantis Velso mokykla, būtent ši saugumo samprata esanti tikroji, ontologinè. Pačia pirmine prasme, tai yra ryšys tarp vaiko ir motinos, pirmapradis žmogaus saugumo jausmas, socialinio santykio kategorija, vieno saugumas kitame ${ }^{34}$. Pozityvi buvusi ir semantiné žodžio "saugumas“ prasmè - „saugus“ (ang. "secure") kilo iš lotyniško žodžio "se cura“ - „be rūpesčio“, o tai yra priešinga reikšmé šiandieniam supratimui. Žmogiškosios dimensijos ignoravimas saugumo konceptualizavime prieštarauja logikai - kad „saugumo“ sąvoka turètų prasmę tarptautiniu lygmeniu, ji pirmiausia turi turèti atpažįstamą prasmę individualiu lygmeniu. ${ }^{35}$ "Ontologinis saugumas“ esąs prigimtinis, pasąmoningas, kiekvienam individui nuo kūdikystès būdingas impulsas ar poreikis jaustis saugiai socialiniuose santykiuose ir kontroliuoti situaciją ${ }^{36}$.

„Velso" mokykla neslepia normatyvinės savo darbotvarkès - pasiūlyti tokią saugumo koncepciją, kuri „pagerintų žmonių gyvenimą ir maksimizuotu

\footnotetext{
${ }^{30}$ Kartais šis terminas vartojamas visoms tradicinei sampratai prieštaraujančioms srovèms apibūdinti, saugumo studijų bendruomenès viduje rašant didžiosiomis raidèmis - CSS - turima omeny Velso mokykla.

${ }^{31}$ Booth K., „Security and emancipation“, Review of International Studies, 17, 1991.

${ }^{32}$ Krause K., Williams M., eds., Critical Security Studies: Concepts and Cases, London, UCL Press, 1997.

${ }^{33}$ Waever (29 išnaša)

${ }^{34}$ McSweeney (9 išnaša), p. 13-15.

${ }^{35}$ Ten pat, p. 16

${ }^{36}$ Ten pat, p. $154-156$.
} 
saugumą per integraciją, o ne izoliaciją, per galimybę, o ne būtinybę $e^{\prime / 37}$. Akademikų vaidmuo neturètų būti bešališkas stebejjimas, bet aktyvus ìsitraukimas. Šia prasme CSS galima būtų sieti su Johano Galtungo taikos studijomis. Booth'ui teorijos tikslas yra praktika. Jeigu teorija pretenduoja aiškinti tarptautinius santykius, ji turètų gebėti atsakyti i klausimus apie žmonių saugumą Bagdado gatvėse. Galvojimas apie galvojimą yra svarbu, tačiau galvojimas apie "darymą, yra dar svarbiau ${ }^{38}$. Anot Bootho, teorija esanti praktikos forma, o praktika - teorijos forma. Griežtai jų atskirti negalima.

\subsubsection{Paryžiaus mokykla}

Kita kritinè saugumo studijų kryptis yra vadinamoji Paryžiaus mokykla su Didier Bigo ${ }^{39}$ ir Jef Huysmansu priešakyje. Šios mokyklos įkvėpëjas - Bourdieu ir kiti sociologai, iš dalies ir Michel Foucault. Pagrindiné šios krypties tezė ta, kad tarp saugumo studijų ir saugumo politikos yra labai glaudus ryšys, o saugumo teoretikai nuo pat saugumo studiju pradžios tiesiogiai veikè valstybių politiką. Todèl šie tyrinètojai empiriškai nagrinejja įvairių valstybinių, nevalstybiniu ir kitokių agentūru, susijusių su saugumu, praktiką, veiklą, procesus, vykstančius už oficialaus diskurso ribų. Skiriamasis šios mokyklos bruožas - „vidaus“ ir "tarptautinio saugumo" susiejimas. Teritorijai šiuolaikiniame pasaulyje prarandant ankstesnę prasmę, i̇vairios saugumo agentūros - policija, kariuomenè, pasienio tarnybos ir t. t. - ima varžytis dẻl saugumo funkcijų. Tokiu būdu kuriamas „naujujų", ,transnacionalinių" grésmių naratyvas, esą anksčiau buvusios tarptautinès grésmės -imigracija, terorizmas, organizuotas nusikalstamumas peržengia valstybiu sienas ir grasina visuomenès vidaus gyvenimui. Taigi visuomenès jaučiamas "nesaugumas" yra minètų agentūru saugumo diskurso ir saugumo politikos pasekmè. Skirtingai nei Kopenhagos mokyklą. Paryžiaus mokyklos atstovus domina empiriné saugumo praktika, o ne diskursas. Metodologiniu požiūriu tai, be abejonès, itin sudètinga prieiga, viena vertus priartëjanti prie eksperimentinio, indukcinio mokslo, antra vertus, balansuojanti ant ,konspiracijos teorijos" ribos.

\subsubsection{Kopenhagos mokykla}

Pagaliau bene labiausiai spejjusi įsitvirtinti saugumo studijų srovė yra Kopenhagos mokykla, kuri sujungè avangardines konstruktyvistų (Węver) ir

\footnotetext{
${ }^{37}$ Booth K., "Security and Self: Reflections of a Fallen Realist" in Krause K., Williams M., eds., Critical Security Studies: Concepts and Cases, London: UCL Press, 1997, p. 105.

${ }^{38}$ Ten pat, p. 114.

${ }^{39}$ Pavyzdžiui, Bigo D., ,When two become one: internal and external securitisations in Europe“, žr.: Kelstrup M., Williams M. C., eds., International Relations Theory and the Politics of European Integration. Power, Security and Community, London, Routledge, 2000, p. 171-205; taip pat Huysmans J., „Defining social constructivism in security studies. The normative dilemma of writing security“, Alternatives 27, Supplement, p. 41-62.
} 
neorealistu (Buzan) intelektualines pajėgas ${ }^{40}$. Trys pagrindinès šios mokyklos koncepcijos yra saugumizacija, sektoriai ir regioniniai saugumo kompleksai. Ši mokykla daugeliu aspektų yra artimiausia „viduriniojo kelio“ konstruktyvizmui.

Anot šios mokyklos, „,saugumo“ terminas reiškia nesugebëjimą išspręsti problemu "normalios politikos“ keliu. Ypatinga saugumo grèsmių prigimtis pateisina neịprastų priemonių naudojimą joms spręsti. Saugumizavimas reiškia, jog tam tikra problema kelia egzistencinę grèsmę, kurią reikia stabdyti. Atitinkamai desaugumizavimas reiškia tam tikro klausimo grąžinimą iš "grésmè-gynyba" diskurso ị ịprastą viešosios politikos sritį. Taigi pagrindinis klausimas turètų būti ne kaip užtikrinti saugumą, bet kas, kaip ir kodèl vieną ar kitą problemą paverčia saugumo problema. Svarbu pažymèti, kad šios teorijos atstovai neatmeta galimybės, jog tam tikrais atvejais problemos saugumizavimas yra neišvengiamas (pavyzdžiui, tiesiogine agresija prieš valstybę) arba reikalingas, siekiant atkreipti dèmesi i i iš tikrujų sudètingą problemą (pavyzdžiui, ekologinès taršos). ${ }^{41}$ Tačiau net ir tokiu atveju, kai „priešiški tankai kerta valstybès sieną“, grèsmè („priešiški“) yra socialinio santykio atributas, o ne tanku per se.

Saugumizavimo teorija pateikia aiškius atsakymus i anksčiau minètas problemas: 1) Saugumo objektu tampa tai, ką nurodo saugumizuojantis veikèjas. Tokiu objektu gali tapti ir individu grupè, ir retų paukščių populiacija, ir badaujantys Afrikos vaikai. Ne visi bandymai saugumizuoti (,,saugumizuojantys kalbos aktai“) pavyksta: tam tikra problema tampa saugumo problema, kai "kalbos akto“ auditorija ją priima kaip tokią problemą. 2) Objektyvios grésmès neegzistuoja - jas socialiai sukonstruoja saugumizuojantys veikejjai, nurodantys vieną ar kitą veiksni kaip „egzistencinę grèsmę“. 3) Valstybé (Kopenhagos mokyklos požiūriu) išlieka „idealiu saugumo veikèju“ “42, kuris istoriškai užima privilegijuotą poziciją ir yra geriausiai pasiruošęs atlikti saugumo užduotis. 4) Pagrindiniai saugumizavimo teorijos postulatai leidžia daryti gana paradoksalią išvadą, jog geriausias būdas išspręsti saugumo problemą yra problemos desaugumizavimas. Jeigu problemą galima išspręsti įprastos politikos priemonèmis, nebelieka pagrindo „identitetu“ konfliktui ir jègos panaudojimui stabdant grèsmę.

Wæver'is ir Buzan'as atmeta galimybę objektyviai apibrèžti saugumo reikšmę. Anot ju, saugumo reikšmę lemia veikejjai, todèl saugumas yra neišvengiamai subjektyvi koncepcija. Vis dèlto šie autoriai, kaip ir konstruktyvizmo mokykla apskritai, dar nèra įveikusi "dvigubos hermeneutikos" spąstų. Teigdami, kad tam tikrą saugumo reikšmę saugumizuojančiu kalbos aktu sukonstruoja socialiniai veikejjai, Wæver' is ir Buzan'as vis dèlto nurodo, kokios „,specifinès retorinės struktūros" reikia ieškoti tekstuose - tokios, kurioje

\footnotetext{
${ }^{40}$ Pagrindiniai kūriniai: Wæever O., Buzan B., Kelstrup M., Lemaitre P., Identity, Migration and the New Security Agenda in Europe, London, Pinter, 1993; Waever O., „Securitization and Desecuritization“, žr.: Lipschutz. R. D., ed., On Security, New York: Columbia University Press, 1995; Buzan B., Waever O., de Wilde J., Security: a New Framework for Analysis, London, Lynne Rienner, 1998.

${ }^{41}$ Miniotaitė, Jakniūnaitė (4 išnaša), p. 9.

${ }^{42}$ Buzan, Wæver, de Wilde, (40 išnaša), p. 37.
} 
daroma nuoroda į „,egzistencines grèsmes“ ir būtinybę su jomis kovoti. Bẻgdami nuo ontologinio, objektyvistinio saugumo apibrěžimo, jie neišvengia a priorinio saugumo konceptualizavimo, kuris iš esmès atmeta bet kokią kitą saugumo sampratą, kuri gali būti nesusijusi su egzistencinėmis grèsmèmis.

Ypač aršiai šią saugumizavimo teorijos spragą kritikuoja McSweeney ${ }^{43}$, kuris, kaip minèta, teigia, kad saugumą galima suvokti ne tik neigiama (saugumas nuo ko?), bet ir teigiama prasme (saugumas kam?), o saugumas turi prasmę tik tada, kai jo pirminis subjektas yra žmogus. Kopenhagos mokykla, kaip ir "viduriniojo kelio“ konstruktyvizmo atstovai apskritai, atmeta toki "metodologinị individualizmą" ${ }^{44}$. Anot Wendto, studijuoti tarptautinius santykius nestudijuojant valstybių būtų tas pats, kas studijuoti mišką nekreipiant dèmesio į medžius. Todèl „viduriniojo kelio“ konstruktyvizmas išlieka racionalizmo ontologijos gniaužtuose, kur valstybė yra bet kokios tarptautiniu santykių analizės atskaitos taškas.

Konstruktyvistų „p politinė“ darbotvarkè turi tam tikrą normatyvinį pagrindąsiekti problemu ",desaugumizavimo", tai yra jų grąžinimo į normalią politiką. Kaip minèta, tam tikrais atvejais kai kurias problemas yra būtina "saugumizuoti“" kad i jas būtų atkreiptas visuomenės dėmesys (pavyzdžiui, Darfuro krizė). Kai kurie konstruktyvistai tokiems atvejams apibūdinti naudoja „pozityvaus saugumizavimo" koncepciją. Tuo pat metu ima ryškèti ir konstruktyvistų bandymai didinti savo įtaką politikų sprendimams i politikos analizę ir rekomendacijas orientuotais straipsniais ar studijomis. Galima tikètis, jog, kaip ir nuo 1940-ujų m. amerikiečiu strategai viešajame diskurse ịtvirtino nacionalinio saugumo, atgrasinimo, galios politikos, saugumo dilemos ir panašias koncepcijas, konstruktyvistams pavyks įdiegti identiteto, normu, desaugumizavimo terminologiją į tarptautinių santykiu diskursą ir eventualiai - i praktiką.

Saugumizavimo koncepcija turi tam tikrą aiškinamąją analitinę vertę, kuria reminatis galima į tradicinius tarptautinès politikos klausimus pažvelgti netradiciškai, naujai. Kariniu pajėgų skaičius ar ekonominiai ištekliai nėra visa lemiantys veiksniai tarptautiniuose santykiuose - ne mažiau svarbios gali būti ir vertybès, kultūra, visuomenès (įskaitant politinio elito, priimančio sprendimus) mentalitetas. Nuosaikesni konstruktyvistai neatmeta galios svarbos, netgi atvirkščiai: kad saugumizuojantis kalbos aktas pavyktų, veikëjas turi užimti tam tikrą valdžios poziciją. Praktinès pasekmès tarptautiniams santykiams būtų visiškai skirtingos, jeigu teiginį, kad ŽIV plitimas Afrikoje yra saugumo problema, pasakytu „,Greenpeace“ narys ir jeigu tą pati pasakytų Tony Blair'as ar George W. Bush'as.

\footnotetext{
${ }^{43}$ McSweeney B., „Identity and Security: Buzan and the Copenhagen School“, Review of International Studies 22, 1996, p. 81-93; McSweeney B., „Durkheim and the Copenhagen School: a Response to Buzan and Waever", Review of International Studies, 24, 1998, p. 137-40.

${ }^{44}$ Buzan B., Waever O., „Slipper? Contradictory? Sociologically Untanable? The Copenhagen School Replies“, Review of International Studies 23, 1997, p. 241-250.
} 


\subsubsection{Radikalus postmodernizmas ir feminizmas}

Radikalūs postmodernistai, kurie įkvėpimo semiasi Derrido, Foucault, Nietzsche's, Heideggerio filosofijoje, nesiūlo savo saugumo teorijos - jie kvestionuoja ir kritikuoja saugumą apskritai. James Der Derrianas, Walkeris ir panašūs autoriai savotiškai postmodernizuoja saugumą, keldami klausimą, kodèl saugumas turètų apskritai kam nors rūpèti - geriau gyventi įdomu ir neprognozuojamą gyvenimą ${ }^{45}$. Dabar dominuojančio saugumo naratyvo sąlygomis (kuriame dominuoja terorizmo, Rugsëjo 11-osios, masinio naikinimo ginklų, paukščiu viruso, ir kiti grèsmès įvaizdžiai) tokios idejos lyg ir atrodytu juokingos. Antra vertus, radikali postmodernistinè pozicija tradicinèse saugumo studijose vykstančiuose debatuose apie pasauli po „Rugsẻjo 11-osios“" gali turèti tiesioginiu politikos implikaciju. Kiek toli galima nueiti „,saugumizuojant" terorizmą kaip totalinę grèsmę (t. y. ribojant žmogaus teises, ịvedant visuotinį sekimą, išleidžiant i gatves ginkluotą policiją ar net karines pajegas ir taip dar labiau didinant nuolatinį baimės jausmą), kol iš esmès pasikeis vakarietiškojo gyvenimo kokybe ir prasmė? Visuotinis karas prieš terorizmą vadovaujantis tradicinès saugumo sampratos principais gali atvesti iki apokalipsiniu pasekmiu, kaip jau minètu Kubos krizės atveju, kai nuostabiai racionali Žaidimų teorija vos neatvede pasaulio prie branduolinio susinaikinimo slenksčio. Vis dèlto dauguma postmodernistų atsisako paisyti konvencinių tarptautinių santykių disciplinų taisyklių ir nebando sieti savo ideju su politikos tyrimais arba rašo visiškai nesuprantamus tekstus savo pačiu susikurta postmodernistine kalba. Viena iš nedaugelio išimčių galima būtu laikyti Der Derriano darbus ${ }^{46}$.

Artimos postmodernizmui feministinès saugumo studijoms skiria nemažą dèmesį $i^{47}$. Didelè dalis jų darbų yra artimi Velso mokyklos idèjoms. Anot feminisčiu, pagrindinis saugumo objektas turètų būti individas, o tradicinès etnocentristinès saugumo studijos yra vyrų sukurto pasaulio produktas. Lytis, be abejonės, feministinėse saugumo studijose yra vienas pagrindiniu kintamuju.

Apibendrinant galima teigti, kad saugumas turi labai daug veidụ: iš esmės ginčijamos koncepcijos problemą išspręsti, matyt, yra neįmanoma, tačiau, saugumas buvo ir bus svarbus kintamasis akademiniuose tyrimuose.

\footnotetext{
${ }^{45}$ Pvz. žr. Der Derrian J., „, The Value of Security: Hobbes, Marx, Nietzsche, and Baudrillard“ žr.: Lipschutz, (40 išnaša) p. 24-45; Walker, (17 išnaša).

${ }^{46}$ Pvz. žr. Der Derrian J. Antidiplomacy: Spies, Terror, Speed, and War, Cambridge: MA: Blackwell, 1992.

${ }^{47}$ Pvz., Tickner J. A., Gender and International Relations: Feminist Perspectives on Achieving Global Security, New York: Columbia University Press, 1992.
} 


\section{Saugumo, kaip kintamojo analizès parametrai}

Ontologinè "saugumo“ koncepcijos prigimtis. Vadovaujantis realistine samprata, saugumas yra objektyvus, „daiktiškas“, išmatuojamas ji galima įsigyti, parduoti, sumažinti ar padidinti. Reflektyvistinè samprata saugumą pirmiausia sieja su socialiniu pasauliu - saugumizacijos teorijos atveju, negatyvų ryši, kritinių teorijų atveju - pozityvu, emancipacinį ryšì. Abiem atvejais saugumui įprasminti reikia mažiausiai dviejų veikèjų: pirmu atveju, kadangi saugumas yra "daiktiškas", vienam veikejjui didinant savo saugumą, kito saugumas mažeja, t. y. vyksta nulinės sumos žaidimas. Antru atveju, kadangi saugumas yra socialinis ryšys, jis žymi spëjamą santykị, kurị, remiantis „viduriniojo kelio" konstruktyvistais, galima interpretuoti kaip „socialiai sukonstruotą realybę", turinčią materialu pagrindą. Vadovaujantis pomodernistais ir postruktūralistais galima išskirti ir trečią ontologinę saugumo sampratą - saugumo sąvoka gali turèti tik diskursinę prasmę tam tikro diskurso/tekstų ribose.

Epistemologijos ir metodologijos problemos. Saugumo studijose JAV, kaip ir tarptautiniuose santykiuose bei politikos moksluose apskritai, racionalistinè epistemologija yra nepajudinamai įsitvirtinusi. Tyrimai, kuriuose netaikoma žaidimų teorija, kiekybiniai ar statistiniai metodai ar mažu mažiausiai nesivadovaujama Gary King, Keohane ir Sidney Verba vadovėlyje ${ }^{48}$ išdèstytais pozityvistinio socialinio mokslinio tyrimo principais, turi mažai šansų patekti į pagrindinių žurnalų - American Journal of Political Science ar American Political Science Review - puslapius. Europietiškoje tarptautinių santykiu tradicijoje galioja reflektyvistinès epistemologijos anarchija: kiek mokyklu, kiek tyrinėtojų, tiek ir požiūrių į analizès metodus bei pačiu metodų. Bene pagrindinis daugumos kritinių saugumo studijų metodologinis instrumentas yra diskurso analizè. Bendriausia prasme diskurso analizę galima apibréžti kaip kokybinį ir interpretacinį bandymą atkurti kalbos, kurią veikëjai vartoja paaiškinti ir suprasti socialiniams reiškiniams, prasmę. Diskursas reiškia tarpusavyje susijusių tekstu, kalbų, rašytinių dokumentų, socialiniu praktiku visumą, kuri padeda kurti reikšmes ir organizuoti socialinį žinojimą. Skirtingai nei kiekybiniu metodu, statistikos, programavimo ar modeliavimo atvejais, šis metodas yra itin reiklus pačiam tyrinètojui. Autorius privalo įtikinti savo auditoriją, kad būtent jo tam tikro socialinio reiškinio konteksto reikšmės interpretacija yra naudinga aiškinant atitinkamus empirinius padarinius ${ }^{49}$.

Pavyzdžiui, studijuoti saugumizavimą reiškia studijuoti diskursą. Saugumo koncepciją lemia tekstinis kriterijus - specifinė retorinė struktūra, kurią pagal tam tikrus bruožus reikia atrasti diskurse. Diskurso, oficialių tekstu analizė leidžia nustatyti, kas, kaip ir kada saugumizuoja įvairias problemas. Diskurso analizė yra iš tikrujų aiškus metodologinis instrumentas, leidžiantis

${ }^{48}$ King G., Keohane R. O., Verba S., Designing Social Inquiry, Princeton: Princeton University Press, 1994.

${ }^{49}$ Abdelal R., Herrera Y. M., Johnston A. I., McDermott R., Identity as a Variable, Harvard University, 2005 , p. 21 
apdoroti empirinius duomenis, kuriuos tyrinėtojui atstoja tekstai, viešasis diskursas. Antra, nepaisant saugumizavimo teorijos loginio nuoseklumo, šios teorijos pritaikymas tarptautinių santykiu praktikai tirti turi tam tikrų spragų.

Pirma, oficialūs tekstai dažnai skiriasi nuo realios valstybių politikos, o svarbiausi tarptautinès politikos sprendimai dažnai yra priimami ne viešai, bet Davido Eastono politinès sistemos , juodojoje dèžèje“ ", kitaip tariant, už uždaru durų. Ar ambicingi Paryžiaus mokyklos bandymai ịlįsti i šią "dėžęe ir atlikti empirinius tyrimus, duos vaisiu, dar sunku pasakyti. Kopenhagos mokyklos atstovai pripažista, kad diskurso analizè menkai padeda nustatant tikruosius veikèjų motyvus ${ }^{50}$.

Antra, konstruktyvistai, pabrèždami socialinę, subjektyvią tikrovès prigimti ir taip problematizuodami ontologines racionalizmo prielaidas, pamiršta suprobleminti savo pačių naudojamus įrankius, visu pirma kalbą. Pavyzdžiui, "kalbos aktą", kuriuo saugumizuojama viena ar kita problema, konstruktyvistai priima kaip socialinį faktą, kurị galima nagrinèti pozityvizmo epistemologijos siūlomais būdais. Radikalesniems konstruktyvistams toks kalbos „objektyvizavimas" nèra priimtinas: kalba yra tik viena iš socialinès tikrovès konstravimo kategoriju, nei mažiau, nei daugiau subjektyvi už bet kurią kitą kategoriją, pirmiausia tarptautinių santykių neverbalinę praktiką.

Analizès lygmuo. Priklausomai nuo teorinès prieigos, problemos pobūdžio ar tyrimo klausimo, analizè saugumo studijose gali būti vykdoma tiek „iš viršaus į apačią“” pradedant nuo tarptautinès sistemos, tiek „nuo apačios i viršü ", pradedant nuo individų veiksmų analizės. Tradicinëje saugumo sampratoje, strateginėse studijose ịprastas analizės lygmuo yra tarptautinè sistema, analizės vienetas - valstybė. Valstybė yra ir saugumo subjektas, užtikrinantis vidinį saugumą gyventojams ir išorinį saugumą sau pačiai, kaip pagrindiniam saugumo objektui. Individu saugumas yra subordinuojamas valstybės saugumui. Kritinèse saugumo studijose vyrauja siekis išplèsti saugumo subjektu ir objektu skaičiu. Idealistinès, emancipacijos teorijos šalininkai teigia, jog žmogus, individas turètų būti pagrindinis saugumo objektas. Kitos teorijos siūlo įtraukti ir kitus galimus saugumo objektus, pavyzdžiui, visuomenę, ekologiją, ekonomines ir finansines sistemas, virtualią erdvę ir t. t. Saugumizacijos teorijos šalininkai teigia, jog saugumo objektą nustato/pasirenka atitinkamą valdžią turintis subjektas, įvardijantis tą objektą ar problemą kaip saugumo problemą.

Normatyviniai pagrindai. Tradicinè saugumo samprata dèl savo objektyvistinio pobūdžio yra už moralès ribu, tačiau tik pačiu šios sampratos apologetų požiūriu, kadangi daugumos reflektyvizmo krypčių atstovai teigia, jog bet kuri teorija turi normatyvini, subjektyvų pagrindą, kuris kyla iš tos teorijos autoriaus sąmoningu ar nesąmoningu, bet vienaip ar kitaip motyvuotu pasirinkimų. Remiantis realistiniu pasaulėvaizdžiu, objektyvi tikrové yra anarchija tarptautineje sistemoje, todèl visos valstybès yra nesaugios, siekia didinti galią ir taip kelia dar didesni pavojų/nesaugumo jausmą vienos kitoms. Realistai gali paaiškinti, kaip veikia tarptautiniai santykiai, bet negali ju ",patobulinti“,

${ }^{50}$ Buzan, Wæver, de Wilde (40 išnaša), p. 176. 
nes saugumo dilema yra neišsprendžiama. Kritinių saugumo studijų krypties atstovai neneigia savo normatyvinio nusistatymo ir idealistiniu pasaulinès taikos siekiu, t. y. padèti suprasti tarptautinès sistemos veikejjams, kaip galima išspręsti saugumo dilemą. Pagaliau saugumizacijos teorijos šalininkai kritikuoja tiek vienus, tiek kitus dèl vienodai subjektyvių normatyvinių nuostatų ir siūlo sąlygiškai objektyvesnį analizès būdą: bešališkai stebèti patį procesą, aiškintis, kaip ir kodèl atsiranda saugumo problemos, ir padeti veikejjams suprasti, kada to reiktu išvengti, o kada - atvirkščiai.

Saugumo rašymas vs. saugumo praktika. Tradicinių saugumo studiju analitikams rašymas apie saugumą ir saugumo praktika yra du visiškai atskiri dalykai: analitikai gali tik aiškinti tarptautinius santykius ir, remdamiesi savo tezėmis, teikti tam tikras politikos rekomendacijas (tai praktikuoja daugybė įvairių tyrimų ir studijų centrų tiek JAV, tiek Europoje), tačiau saugumo praktika esanti išimtinai valstybės ir jai atstovaujančių valstybininkų prerogatyva.

Kritinių saugumo studiju atstovai susiduria su etine dilema: saugumo analitikai, „rašydami“ apie saugumą, iš esmès dalyvauja saugumo politikos formavimo procesuose ir taip gali daryti įtaką saugumo praktikai (saugumizacijos teorijos atveju - teoretikas gali tapti saugumizuojančiu veikejju, jeigu tam tikru būdu atliks vadinamaji „,kalbos aktą“ - parašys/pasakys, kad tam tikras dalykas yra saugumo problema, kuri turi būti sprendžiama neiprastomis priemonėmis). Ši dilema kritinėse saugumo studijose iki šiol neišspręsta: kritikuodami tradicionalistų "rašymą" už daromą negatyvią įtaką "praktikai“, reflektyvistai nesiryžta patys nurodyti, kas yra saugumo problemos ir kaip jas reikia spręsti.

Antra, pats Booth pripažįsta, kad „didžioji dalis tyrimų iš tikrujjų yra knygos apie knygas, straipsniai apie straipsnius, studijos apie studijas. Tuo pat metu žmonès yra toliau kankinami ir žudomi. Jeigu akademikai nori ne tik „šaudytis iš savo dramblio kaulo bokštu“ ", jie turi paisyti realybès ${ }^{51}$. Nesaugumo jausmas šiandien tvyrantis Bagdado ar Londono gatvėse, nèra vien subjektyvus socialinis konstruktas - tų miestų gyventojams tai yra pakankamai objektyvios, materialinès gyvenimo sąlygos. Diskurso analizè ne tik negali nei įtikinamai išspręsti šios saugumo problemos, nei juo labiau pakeisti tu gyvenimo sąlygų. Apibendrinant galima teigti, kad saugumo teorijos ir praktikos visiškai atriboti neįmanoma - „fundamentaliosios" saugumo studijos tiesiog neturètų prasmès be taikomojo elemento. 2 lentelè.

Aptartus saugumo, kaip kintamojo, analizès parametrus apibendrina

${ }^{51}$ Booth K., (37 išnaša), p. 107, 113. 


\begin{tabular}{|c|c|c|c|c|c|c|c|c|c|}
\hline 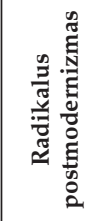 & & 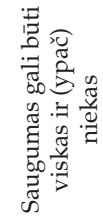 & \multirow{3}{*}{ 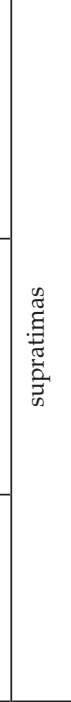 } & \multicolumn{6}{|c|}{ 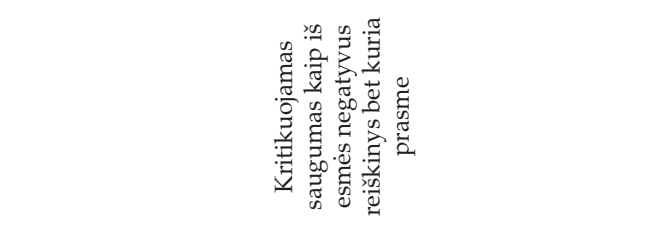 } \\
\hline \multirow{2}{*}{ 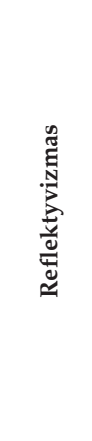 } & 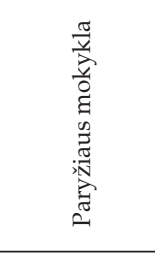 & 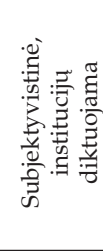 & & \multirow{2}{*}{ 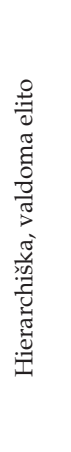 } & \multirow{2}{*}{ 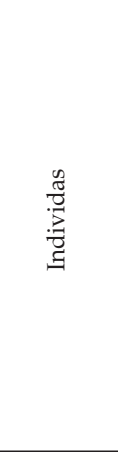 } & 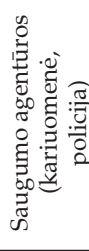 & & 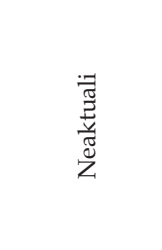 & 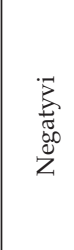 \\
\hline & 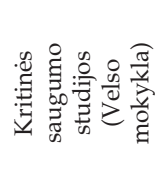 & 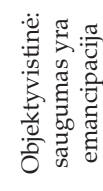 & & & & 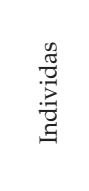 & 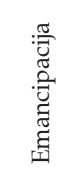 & 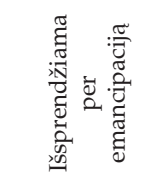 & 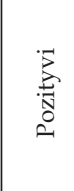 \\
\hline \multirow{4}{*}{ 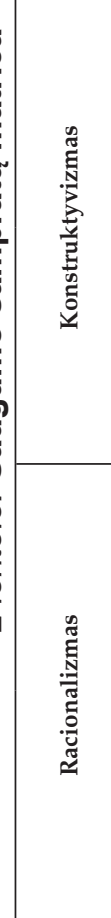 } & 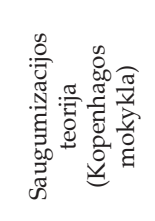 & 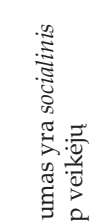 & \multirow{4}{*}{ 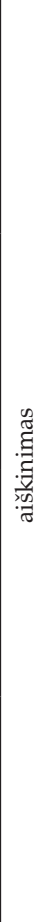 } & \multirow{2}{*}{ 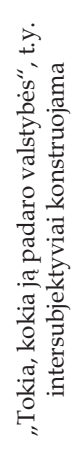 } & 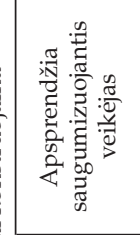 & 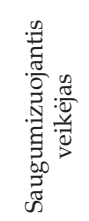 & 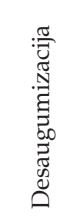 & & $\vec{B}$ \\
\hline & 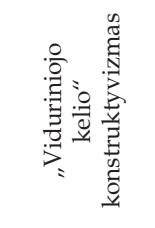 & 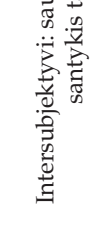 & & & 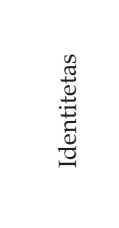 & \multirow{3}{*}{ 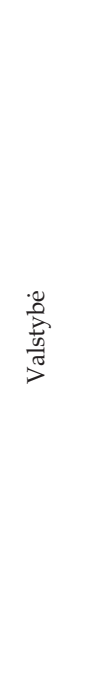 } & & 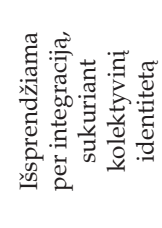 & $z^{\infty}$ \\
\hline & 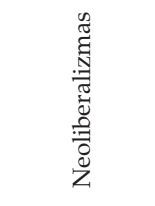 & 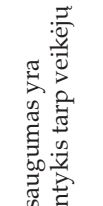 & & 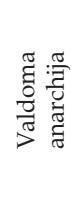 & \multirow{2}{*}{ 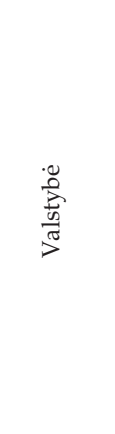 } & & 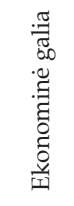 & 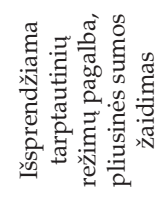 & 点 \\
\hline & 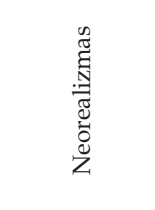 & 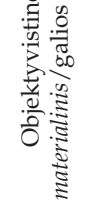 & & 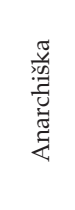 & & & 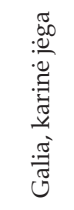 & 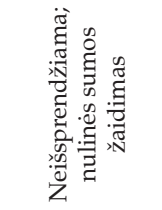 & 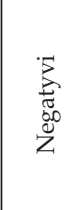 \\
\hline 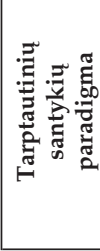 & 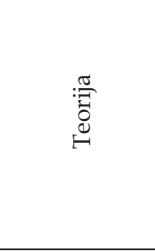 & 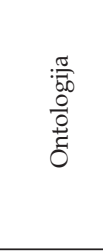 & 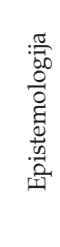 & 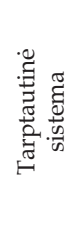 & 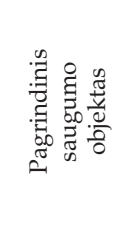 & 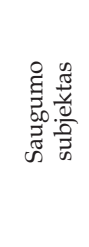 & 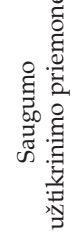 & 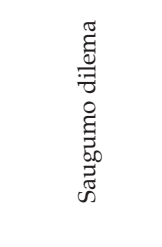 & 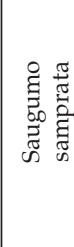 \\
\hline
\end{tabular}




\section{Išvados}

Saugumo studijos šiandien išgyvena pakilimą. Europietiškos saugumo studijų mokyklos yra metusios rimtą iššūki ortodoksinei JAV saugumo/ strateginių studiju tradicijai. Saugumo samprata šioje tradicijoje iki šiol yra suprantama kaip materiali, ikiteorinè duotybè. Kopenhagos, Paryžiaus, Velso mokyklos „iš esmès“ èmèsi „iš esmès ginčijamo“ klausimo „kas yra saugumas"?, nekylančio JAV dominuojantiems racionalizmo proponentams. Konservatyvios saugumo studijų subdisciplinos savotiškas suklestëjimas kartu suteikė svarbų impulsą tarptautinių santykių studijoms Europoje.

Lietuvoje įsitvirtinusi geopolitika didele dalimi veikia ir formuoja tiek politikos mokslų studentu, tiek ir politinio elito pasaulezžiūrą bei saugumo suvokimą. Kol kas tik vienas kitas lietuvių akademikas bando išsiveržti už pakankamai siaurų lietuviškojo saugumo/geopolitinio diskurso rẻmų ir dalyvauti europinio lygmens saugumo studiju diskurse. Platesnè ir įvairesnè saugumo teoretikų ir analitikų diskusija Lietuvoje būtų sveikas ir sveikintinas reiškinys, kuris galètų reikšmingai praturtinti ir pačią Lietuvos saugumo politiką.

Jeigu strateginių tyrimu centrų orientacija į praktinių saugumo problemu analizę ir sprendimus atrodo natūrali ir logiška, akademinès institucijos, lietuviu politologai ir sociologai, politikos mokslų studentai galètų skirti daugiau dėmesio fundamentaliems saugumo tyrimams. Juolab kad šiame straipsnyje aptarti galimi saugumo, kaip kintamojo, analizès parametrai leistu daryti prielaida, kad egzistuoja gana plati erdvè teoriniams, praktiniams ir ypač tarpdisciplininiams saugumo problemu tyrimams plètoti.

Šiuolaikinėse saugumo studijose tyrinètojas gali rinktis iš esmès tarp dvieju normatyviniu pozicijų: pozityvistinès, kai tyrinètojas remiasi objektyvistine saugumo ontologija, arba konstruktyvistinès, kai teksto autorius supranta savo vaidmenį konstruojant atitinkamą saugumo naratyvą. Pirmuoju atveju yra galimas nesąmoningas autoriaus indèlis i konkrečios problemos paaštrinimą, saugumizavimą arba sprendimą, taip iš esmès prarandant saugu akademinį nešališkumą. Antruoju atveju pirmasis pavojus yra įsisąmonintas, todèl arba autorius (pavyzdžiui, atstovaujantis Velso mokyklai) savo tekstu sieks paveikti praktiką, arba sąmoningai vengs tokio poveikio (Paryžiaus, Kopenhagos mokyklos). Bet kuriuo atveju normatyvinis šališkumas analizès objekto atžvilgiu yra neišvengiamas, o saugumizacijos teorija subjektyvumą gali amortizuoti tik iš dalies.

Saugumas gali būti tiriamas ir kaip objektyvus, materialius duomenis turintis reiškinys, ir kaip intersubjektyvus socialinis santykis tarp dviejų veikëju, ir kaip refleksyvinė specifinè retorinė struktūra tam tikram tekste. Svarbiausia, kad tyrinètojas priimtu ir i̇sąmonintų saugumą kaip kintamajị ir nesistengtu teigti saugumo kaip neišvengiamos egzistencinès duotybès.

Saugumo studijose, kaip ir tarptautiniuose santykiuose apskritai, analizès lygmuo ir analizės vienetai yra tyrinėtojo jurisdikcijoje ir didele dalimi priklauso nuo nagrinëjamos teorinės ar praktinès problemos: saugumui vienokia ar kitokia prasmé gali būti suteikta individualiu, grupés, valstybès ar tarptautinès 
sistemos lygmeniu, todèl čia atsiveria erdvė tarpdiscipliniams tyrimams psichologu ir sociologu ižvalgos apie individo sąmonę ar kolektyvinį elgesi jau yra įsiskverbusios i europines saugumo studijas.

Saugumo epistemologijos fronte nieko naujo: autoriai, kurie siekia saugumą paaiškinti, negali pasiūlyti saugumo supratimo, ir atvirkščiai - autoriai, siekiantys suprasti saugumą, negali pasiūlyti priimtino jo aiškinimo. İtampos tarp šių dviejų polių mažinimas turètų būti vienu pagrindinių iššūkių kritinių saugumo studijų atstovams. Mesti rimtą iššūki tradiciniu saugumo studijų atstovams galima tik ju pačių epistemologijos „,aikštelëje“. Kitaip tariant, pagrindinius konstruktyvistų metodologinius instrumentus - diskurso analizę, interpretaciją, sociologinius metodus - būtina įvilkti į pozityvistinio tyrimo rūbą, norint iggytą saugumo supratima panaudoti aiškinimui.

Saugumo praktika neabejotinai daro įtaką saugumo rašymui, ir atvirkščiai: rašymas apie saugumą gali turèti ir dažnai turi pasekmių saugumo praktikai, tačiau nebūtinai ir ne visada pozityvių. Saugumo studijų raison d'etre turètų būti atsakymas į klausimą, kaip saugumo rašymu padèti spręsti saugumo praktikos problemas, ne tik jas bandyti suprasti ar paaiškinti.

Briuselis, 2006 m. rugsëjis 